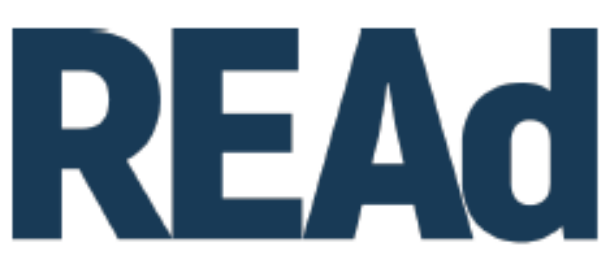

Revista Eletrônica de Administração

\title{
A PANORAMA OF MARIANA AND BRUMADINHO DISASTERS: WHAT DO WE KNOW SO FAR? ${ }^{1}$
}

\author{
Sarah Amaral Fabrício ${ }^{2}$ \\ Denize Demarche Minatti Ferreira ${ }^{3}$ \\ José Alonso Borba ${ }^{4}$
}

http://dx.doi.org/10.1590/1413-2311.310.102806

\begin{abstract}
In 2015, the Fundão dam of the company Samarco (controlled by Vale) collapsed, causing a huge wave of mud, causing 19 deaths and becoming the biggest environmental disaster in Brazil. As early as 2019, a new dam rupture took place, with Vale as the responsible company, with around 270 fatalities. Both disasters brought numerous social, environmental and financial problems. This study aims to analyze the impact of environmental disaster of Brumadinho and Mariana on Vale and Samarco Financial Statements, specifically the problems related to provisions, contingencies and environmental processes. The method employed with the case study was a content analysis, and data collection was carried out from Financial Statements, Reference Form and the company's press channel over a 10-year period from 2010 to 2019. Among the main results, we observed that in 2015, the Mariana dam collapse may explain the significant increase in the coming years regarding deposits and provisions for environmental actions filed against Samarco and Vale. In 2019, it is observed that the amount moved to judicial deposits increased 45 times compared to the previous year. Considering this fact, there is a need for studies that contribute to the transparency of actions for the victims, communities affected by the tragedy, disregard of those involved and the environment, since this is not the first disaster caused by this company.
\end{abstract}

Keywords: Provision; Contingencies; Disaster; Brumadinho; Mariana.

\footnotetext{
${ }^{1}$ Recebido em 8/5/2020, aceito em 10/2/2021.

${ }^{2}$ Universidade Federal de Santa Catarina - Programa de Pós-graduação em Contabilidade; Florianópolis (SC) Brasil; http://orcid.org/0000-0002-5078-8743; sarahamaralfabricio@gmail.com.

${ }^{3}$ Universidade Federal de Santa Catarina - Programa de Pós-graduação em Contabilidade e Departamento de Ciências Contábeis; Florianópolis (SC) - Brasil; http://orcid.org/0000-0002-4661-9672; denize.minatti@ufsc.br.

${ }^{4}$ Universidade Federal de Santa Catarina - Programa de Pós-graduação em Contabilidade e Porgorama de PósGraduação em Administração; Florianópolis (SC) - Brasil; http://orcid.org/0000-0001-6068-342X; j.alonso@ufsc.br.

(c) (1) (9) REAd | Porto Alegre - Vol. 27 - N.ㅇ 1 - Janeiro / Abril 2021 - p. 128-152.
} 


\section{PANORAMA DOS DESASTRES DE MARIANA E BRUMADINHO: O QUE SABEMOS ATÉ AGORA?}

Em 2015, ocorreu o rompimento da barragem de Fundão da empresa Samarco (controlada pela Vale), causando uma enorme onda de lama, causando 19 mortes e tornando-se o maior desastre ambiental do Brasil. Logo em 2019, um novo rompimento de barragem aconteceu, tendo como empresa responsável a Vale, tendo em torno de 270 vítimas fatais. Ambos os desastres trouxeram inúmeros problemas socioambientais e financeiros. O estudo tem como objetivo analisar o impacto do desastre ambiental de Brumadinho e Mariana nas Demonstrações Financeiras da Vale e Samarco, especificamente os problemas relacionados às provisões, contingências e processos ambientais. O método empregado no estudo de caso foi a análise de conteúdo e, a coleta de dados foi realizada a partir das Demonstrações Financeiras, Formulários de Referência e "press release" da empresa num período de 10 anos compreendido entre 2010 a 2019. Entre os principais resultados, observamos que em 2015, o colapso da barragem de Mariana pode explicar o aumento significativo de depósitos e provisões para ações ambientais movidas contra a Samarco e a Vale nos anos seguintes. Em 2019, detectou-se que o valor transferido para depósitos judiciais aumentou 45 vezes em relação ao ano anterior. Considerando esse fato, são necessários estudos que contribuam para a transparência das ações das vítimas, comunidades afetadas, desrespeito aos envolvidos e ao meio ambiente, pois esse não é o primeiro desastre causado pela empresa.

Palavras-chave: Provisão; Contingências; Desastre; Brumadinho; Mariana.

\section{PANORAMA DE LOS DESASTRES DE MARIANA Y BRUMADINHO: ¿QUÉ SABEMOS HASTA AHORA?}

En 2015, la represa Fundão de la empresa Samarco (controlada por Vale) se derrumbó, provocando una gran ola de lodo, provocando 19 muertos y convirtiéndose en el mayor desastre ambiental de Brasil. Ya en 2019, se produjo una nueva ruptura de presa, con Vale como empresa responsable, con alrededor de 270 muertes. Ambos desastres trajeron numerosos problemas sociales, ambientales y financieros. Este estudio tiene como objetivo analizar el impacto del desastre ambiental de Brumadinho y Mariana en los estados financieros de Vale y Samarco, específicamente los problemas relacionados con provisiones, contingencias y procesos ambientales. El método utilizado en el estudio de caso fue el análisis de contenido y la recopilación de datos se realizó mediante los estados financieros, formularios de referencia y comunicados de prensa de la compañía durante un período de 10 años de 2010 a 2019. Entre los principales resultados, observamos que en 2015, el colapso de la presa Mariana puede explicar el aumento significativo de depósitos y provisiones para acciones ambientales presentadas contra Samarco y Vale en los años siguientes. En 2019, se descubrió que el monto transferido a depósitos judiciales aumentó 45 veces en relación con el año anterior. Teniendo en cuenta este hecho, se necesitan estudios que contribuyan a la transparencia de las acciones de las víctimas, las comunidades afectadas, la falta de respeto por los involucrados y el medio ambiente, ya que este no es el primer desastre causado por la empresa.

Palabras clave: Provisión; Contingencias; Desastre; Brumadinho; Mariana. 


\section{INTRODUCTION}

The concept of sustainability permeates the debate between business and environmental issues, enhancing a motivation not only to the academic community, but also to the private sector, especially, companies. The industry operations occur in everywhere on the planet, in different ecosystems. These operations often put great pressures on the local environment and people, and as global population growth continues to rise, so too does the demand for useable energy and resources.

Therefore, legal matters regarding environmental issues have started to be frequent among corporate contingencies, which does not mean that companies are polluting or infringing more. This is a result of growing investors' demands for disclosure of potential environmental liabilities, stricter regulation of accounting policies, and the oversight of federal and state agencies, which has led to a higher volume of assessments and legal discussions, with provisions emerging as a result.

Throughout the $20^{\text {th }}$ century, and particularly over the past 50 years, people's exposure to disaster risks has grown in Brazil and worldwide faster than their vulnerability reduction capabilities, resulting in intense and extensive (in time and space) negative impacts (FREITAS et al., 2016).

Among the world's largest environmental disasters are: Union Carbide India Limited which injured more than 500,000 people in Bhopal in India, Exxon Valdez leaked the equivalent of 700,000 barrels of oil in Alaska, the British oil company BP was fined US\$ 4.5 billion by the US government on criminal charges related to the environmental disaster with the Deepwater Horizon platform in the Gulf of Mexico in 2010.

In Brazil, significant environmental disasters have had negative impacts on the environment, including those related to companies: such as the oil spills in Tramandaí, Araucária and Rio de Janeiro caused by Petrobras S.A.; Chevron Corp. at Campos Basin in Rio de Janeiro, among others. Recently, two major disasters that led to the death of many people as well as immeasurable and irrecoverable damage were caused by the same company, Vale, both in the state of Minas Gerais. Mining activities produced large amounts of waste accumulated in the dams. In Brazil there are hundreds of dams with mining waste and over 40 are unstable and at full capacity in Minas Gerais alone (MEIRA et al., 2016).

In 2015, the Fundão dam collapsed, where Vale controlled Samarco, in partnership with the Anglo-Australian BHP Billiton, which left 19 fatal victims and caused a flood of mud 
that provoked a number of mudslides, is the largest environmental disaster in the history of Brazil.

In 2019, The first dam of Córrego do Feijão Mine, also operated by Vale, collapsed and, nowadays, is the biggest environmental disaster of three decades in terms of human tragedy. Consequently, the disaster caused by Córrego do Feijão dam collapse should be understood not as an exception, but as part of the human, social and environmental costs that this type of event has been causing to the world.

Therefore, the Brumadinho dam disaster is an example of infrastructure failure with catastrophic consequences. The environmental impact is massive and difficult to quantify. As a result, these disasters demonstrate that the current assets for monitoring integrity and generating alerting managers, authorities and the public to ongoing change in tailings are, in many cases, not working as they should. There is also a need for adequate prevention procedures (SOUZA, 2019).

The Córrego do Feijão dam is part of the Paraopeba's Complex, located in Brumadinho (Brazil) and owned by Vale, the world's largest producer of iron ore. Created in 1942 during Getúlio Vargas government, Vale S.A. is a privately held and publicly traded company listed on the São Paulo, Paris, Madrid and New York Stock Exchanges.

Disasters have indicated the need for enforceable international and local standards for environmental safety, provisions and continent liabilities and preventative strategies to avoid similar accidents and similar industrial disasters.

Thus, given the environmental disasters that have occurred in recent years, companies are expected to periodically report on how the organization is meeting current standards, what business sustainability program is in place, how the company identifies and prevent environmental risks (SILVA, 2019).

Following these events, researchers, policy makers, and public interest organizations pondered insights and recommendations aimed at improving future planning and responses to large-scale environmental disturbances (REAMS et al., 2017).

This problem has attracted more attention and companies have been more concerned with social and environmental issues. Widely, the disclosure of information on investments is more detailed. Mainly, because society has demanded from companies the positioning of the actions they perform and even a deeper discussion about the social and environmental issues that they disclose in their reports.

The disclosure of environmental information became important throughout the 1990s and has been a significant manifestation of companies' interaction with the environment, (c) $\underset{1}{(1) \Theta(}$ REAd | Porto Alegre - Vol. 27 - N.o 1 - Janeiro / Abril 2021 - p. 128-152. 
however environmental disclosure is not the practice of most companies, it is most often performed by larger companies (GRAY; BEBBINGTON, 2001).

Transparency and reliability are essential to companies' reputation, especially in social and environmental aspects. Thus, recognizing social and environmental responsibility may be related to efficient management, while omission may pose a risk, as external pressures intensify (FERREIRA et al., 2014).

In turn, the national press, through media outlets ( $\mathrm{TV}$, radio and newspapers), gave extensive daily coverage, monitoring and heralding in real time through online pages. As for the extent of what was reported, take as an example: In 2015, the newspaper Folha de São Paulo newspaper published about 600 articles in this period, reflecting the events throughout Brazil and, at the same time, trying to provide a context and relate it to the Vale/BHP/Samarco disaster, which affected the Doce river basin. The newspaper Estado de Minas published approximately 1400 insertions, if considered beyond the specific coverage of the disaster, all mentions, opinion columns, testimonials, interviews and cartoons on the subject (ESPINDOLA; GUIMARÂES, 2019).

Among the many textual genres that comprise the media, stands out the one that perhaps most reinforces such an idea of impartiality is: the news. In contrast, the news are not an exact mirror of reality (RODRIGUES, 2019).

Zhouri (2018) warns that the way mining invades territories produces power games and successive socio-environmental crisis that have been discussed in the social sciences. According to the author, new legal frameworks have favored simplified environmental licensing processes in Brazil, including mining, waste management, railroad transportation and port sector operations. There are plenty of specialized consultants available to ease the content of licensing and business responsibilities in the face of possible damage, which favors the occurrence of disasters. In short, disasters entail far more than a set of material damages that can be measured and solved through financial compensation. The rehabilitation process itself can be replete with various dimensions of violence that further degrade the living conditions and autonomy of those who suffer losses. Disasters, therefore, are not limited to the critical catastrophic event, but rather unfold into long-lasting processes of social crisis, often intensified by institutional guidelines, which have the effect of perpetuating social suffering (ZHOURI et al., 2017).

There is a need for studies that contribute to the transparency of actions for the victims, communities affected by the tragedy, disregard of those involved and the environment, since this is not the first disaster caused by this company. 
In light of the above, a question arises: What are the impacts related to provisions, contingencies and environmental processes at Vale S.A. after the Brumadinho and Mariana disasters? Hence, this study aims to analyze the impact of environmental disaster of Brumadinho and Mariana on The Financial Statements Vale S.A. and Samarco, specifically the problems related to provisions, contingencies and environmental lawsuits.

In general, all provisions are contingent since there is uncertainty as to their term or value. CPC 25 (International Accounting Standard 37) brings the term "contingent" to liabilities and assets that are not recognized as their existence will only be confirmed by the occurrence or not of one or more uncertain future events not entirely under the control of the entity. Additionally, the term contingent liability is used for liabilities that do not meet the recognition criteria. CPC 25 provides the standardization for Provisions, Contingent Liabilities and Contingent Assets in order to ensure that their recognition is in accordance with appropriate criteria and measurement bases and that sufficient information is disclosed so that users can understand their nature, timing and amount (CPC 25, 2009). Kieso, Weygandt, and Warfield (2020) conceptualize contingency as an existing situation involving uncertainty as to possible gain (gain contingency) or loss (loss contingency) that will ultimately be resolved when one or more future events occur or fail to occur. In short, contingencies are material events with an uncertain future. Examples of gain contingencies are tax operating-loss carry forwards or company litigation against another party. Typical loss contingencies relate to litigation, environmental issues, possible tax assessments, or government investigations. To the authors, loss contingencies involve possible losses, a liability incurred because of a loss contingency is by definition a contingent liability, contingent liabilities depend on the occurrence of one or more future events to confirm either the amount payable, the payee, the date payable, or its existence and these factors depend on a contingency.

This research constitutes a relatively new area which has emerged from studies that contribute to transparency, in favor of the communities that were directly and indirectly affected by the tragedy. In addition, few studies have focused on the situation of the involved families and how they treated by the company responsible for the disaster (FREITAS, 2018).

\section{THEORETICAL FRAMEWORK}

\subsection{THE IMPACTS OF DISASTERS ON SOCIETY}


Around the world, the increase of disasters - both natural and technological - is noticeable, which draws the attention of governments and civil society to the matter. These disasters bring not only environmental impacts, but also to the health of those living near affected areas, financial impacts for the companies and also surrounding locations. Not to mention the emotional and traumatic effects on all those involved in the disasters, their families and friends. According to Polignano and Lemos (2020) it is possible to show the different impacts produced by the dam rupture. Some morphological changes in the river system occurred due to the impacts caused by the vegetation removal, erosion on the margins of watercourses, changes in the river layout, and also by the deposition of sedimentary materials in the river bed.

The authors also report that the social impacts of the dam rupture are very complex and include the destruction of public and private structures, alteration of the way of life of traditional communities and loss of intangible heritage, not to mention the loss of productive capacity of small farmers, such as the health of riverside communities and affected individuals (psychological damage, mental health, flood related diseases), proliferation of vectors (rats, insects), restriction of possible uses for the water and limitation of water uses. The consequences of disasters on health and well-being are many.

Apart from causing personal tragedies and collective suffering, increased levels of mortality and morbidity, they indirectly impact the political, social and economic development of affected municipalities, states or countries. Favoring conditions for the risk of new diseases and health problems that overlap with existing ones (OPAS, 2014). And, moreover, when environmental contaminants are involved, it causes damages that provoke abrupt transformations in the social organization and in the historically constituted ways of living and working in the affected areas, with effects on health (FREITAS; SILVA; MENEZES, 2016). Mayorga (2020) reports on the issue of victims', relatives' and residents' mental health in affected cities. The author describes an increase in alcoholism and drug use, all kinds of violence (especially domestic violence), depression, suicides and attempts, some psychotic episodes, as well as psychosomatic effects, such as high blood pressure, allergic episodes, respiratory and skin problems, which may or may not be related to contamination. Along the Paraopeba River, from Brumadinho to Três Marias, the effects of the disaster are perceived in different degrees. Such effects are described by known protocols in the field of emergency and disaster psychology and relate to events that are somewhat predictable in the medium term. It should not be forgotten, however, that this is a disaster/crime still in progress and that the population is in a state of desolation or in political ethical suffering. From the occurrence of (c) (1) $\Theta$ REAd | Porto Alegre - Vol. 27 - N.o 1 - Janeiro / Abril 2021 - p. 128-152. 
disasters, the population' pre-existing vulnerabilities are added to new risk scenarios, producing extremely complex contexts in relation to environmental and health consequences, combined with different levels of uncertainty. Thus, companies seek to reduce their responsibilities and transfer the burden of proof of negative effects on the health of the population to those affected, relying on a legal structure that favors them, to the point of producing subsequent disasters without any radical change in the legal framework and the strengthening of public institutions that must protect the population from risks and care for their health (SILVA; FREITAS; XAVIER; ROMÃO, 2020).

As for the financial impacts, Domingues, Magalhães, Freire, Simonato and Nahas (2020) predict that in the next 2 or 3 years the PIB results of Minas Gerais would lose -0.47 as a result of the tragedy, accompanied by unemployment, reduction of family consumption and investments. Around 15 thousand job positions would no longer be offered in this period and the collection of IPI and ICMS would drop by R $\$ 575$ million. The biggest impact would still be consumption, with an estimated loss of $\mathrm{R} \$ 856$ million. Disasters such as those of Mariana and Brumadinho cannot have their impacts reduced to the municipalities where they occur and those affected by the immediate number of casualties and injuries or even the homelessness (FREITAS et al., 2019).

There is still the problem of the delayed recovery of homes and small businesses from the first disaster (which occurred in 2015, by Samarco). According to D'Oliveira (2020), families in the villages of Bento Rodrigues and Paracatu de Baixo, which were struck by mud almost 5 years ago, are still unsure of when they will have their homes back. Since the beginning of the environmental recovery project and village reconstruction, Renova Foundation has concluded only two houses in the new district. Construction began in new Bento Rodrigues only in July 2019, already behind schedule, the forecast was March 2016. Still, the plan to conclude $85 \%$ of the settlement as a whole was frustrated by the pandemic and is expected to be completed only at the end of 2021.

According to Freitas (2020) by September 2020, Renova had already spent R $\$ 10.1$ billion on remediation and compensation programs. Among its actions, Renova has spent more than R\$ 830 million on education, health and infrastructure investments in cities throughout Rio Doce Basin and has also paid, until August 2020, around $\mathrm{R} \$ 2.6$ billion in indemnities and emergency financial aid to more than 321,000 people. Even informal workers, with difficulties to prove how they were affected, started to be compensated: since August of this year, more than 500 workers of these categories received their compensation and almost 6,000 informal workers registered to have their demands examined by the Foundation. 


\subsection{ENVIRONMENTAL DISASTERS, PROVISIONS AND CONTINGENCIES: RELATED STUDIES}

Environmental disasters are linked to environmental liabilities and companies are responsible for reversing the damage caused either by a fine or other type of penalty. Nowadays, society and financial markets demand better disclosure of these facts that affect not only the environment, but also the financial and economic issues of companies, which has driven companies to disclose more transparently and reliably.

Concerns about environmental protection is growing all over the world, as a direct result of environmental disasters that have had negative impacts on ecosystems and health, affect the cash flow of responsible companies for them and have serious impacts on their reputations (ALAZZANI; WAN-HUSSIN, 2013).

Historically, large dam breaks have caused significant damage to both human life and property (Table 1).

Table 1 - Historical failures of large dams

\begin{tabular}{c|c|c|c}
\hline Date & Location & Release & Impacts \\
\hline $01 / 25 / 2019$ & Brumadinho, Brazil & $12,000,000 \mathrm{~m}^{3}$ & 395 victims (259 casualties and 11 missing people) \\
\hline $11 / 21 / 2015$ & San Kat Kuu, Myanmar & Unknown & 113 casualties \\
\hline $11 / 05 / 2015$ & Mariana, Brazil & $40,000,000 \mathrm{~m}^{3}$ & 19 casualties \\
\hline $09 / 09 / 2008$ & Taoshi, China & $190,000 \mathrm{~m}^{3}$ & 277 casualties and 33 injured \\
\hline $07 / 10 / 1985$ & Stava, Italy & $200,000 \mathrm{~m}^{3}$ & 268 casualties \\
\hline \multicolumn{3}{c}{ Source: adapted from Raman e Liu (2019) }
\end{tabular}

Under such circumstances, several companies are disclosing environmental and social risks, especially if is considered 'material'. In addition, accounting and reporting environmental activities has become increasingly significant to multiple stakeholders - investors, creditors, governments and society, because environmental issues affect companies' financial health.

The theory of disclosure is based on empirical evidence and patterns of analysis from economic theory that explain and predict reality, providing theoretical support for this study, aiming to explain the phenomenon of financial disclosure. Verrecchia's (2001) states that undisclosed information can be interpreted as unfavorable, in which the value of the asset is discounted until the transmission of the information becomes beneficial.

Although the disclosure of social and environmental information is voluntary in Brazil, a transparency movement of public and private organizations grew in the 1980s through the initiative of the Brazilian Institute of Social and Economic Analysis (IBASE). In addition to the 
Social Balance Sheet, companies also choose to disclose their documents in the models of Environmental Reports, Sustainability Report GRI Guidelines (Global Report Initiative), Annual Reports and Integrated Reporting.

In recent years, interest in corporate social responsibility information has increased in recent years. This has led companies to set aside the classic economic view and to adopt the triple bottom line, reporting social, environmental, and financial information, in order to satisfy their stakeholders' needs (MARTÍNEZ-FERRERO et al., 2015). Given this, the subjectivity and complexity in the measurement judgments and probability expressions linked to contingencies and liabilities has been the subject of several studies.

Depending on the degree of risk, recognition or disclosure, contingencies are of great importance. If a certain event is considered of probable occurrence, it should be recognized as a liability, in other words, it ceases to be a contingency and becomes a provision. The difference between contingencies and provisions is the probability of loss, and its improper recognition may distort the financial statements, portraying a different reality from the company's equity situation. The uncertainty and complexity of the methods commonly used for the financial measurement of environmental impacts does not justify the exemption from the recognition and recording of provisions as well as the disclosure of information on environmental contingencies (BECKE, 2004).

Therefore, relevant studies have been published focusing on the assessment and measurement of environmental impacts that may arise from the activities of organizations (Chart 1).

Chart 1: Related Studies.

\begin{tabular}{|c|c|}
\hline Author(s) & Objective and Findings \\
\hline $\begin{array}{l}\text { Cho et al. } \\
\text { (2012a) }\end{array}$ & $\begin{array}{l}\text { The authors examined three potential explanations for the corporate choice to } \\
\text { disclose environmental capital spending amounts. Their findings show that } \\
\text { disclosing firms do not exhibit improved subsequent environmental performance } \\
\text { relative to non-disclosing companies and suggest that companies use the disclosure } \\
\text { of environmental capital spending as a strategic tool. }\end{array}$ \\
\hline $\begin{array}{l}\text { Cho et al. } \\
\text { (2012b) }\end{array}$ & $\begin{array}{l}\text { The authors investigated the extent to which firms' environmental performance is } \\
\text { reflected in perceptions of their environmental reputation and whether environmental } \\
\text { disclosure serves to mediate the negative aspects of poorer environmental } \\
\text { performance associated with those assessments. The results suggest that voluntary } \\
\text { environmental disclosure appears to mediate the effect of poor environmental } \\
\text { performance on environmental reputation and suggest that membership in the DJSI } \\
\text { appears to be driven more by what firms say than what they do. }\end{array}$ \\
\hline $\begin{array}{l}\text { Chen et al. } \\
\text { (2014) }\end{array}$ & $\begin{array}{l}\text { The authors investigated potential motivations for late adopting U.S. companies to } \\
\text { begin disclosing environmental liability amounts in their financial statements. The } \\
\text { overall level of environmental liability amounts was consistently decreasing over the } \\
\text { time frame examined, suggesting that earlier adoption would have made more sense } \\
\text { and may also explain why almost no new firms began disclosing after the mid-2000s. }\end{array}$ \\
\hline
\end{tabular}




\begin{tabular}{|c|c|}
\hline $\begin{array}{l}\text { D'Amico et al. } \\
\text { (2016) }\end{array}$ & $\begin{array}{l}\text { The authors analyzed the effects produced by the introduction of specific legislation } \\
\text { on environmental disclosures. The analysis shows an (excessively) low level of } \\
\text { disclosure of environmental information by the companies and that the introduction } \\
\text { of legislation as purely voluntary only affects the contents of quantitative } \\
\text { environmental disclosures. }\end{array}$ \\
\hline $\begin{array}{l}\text { Ching et al. } \\
\text { (2017) }\end{array}$ & $\begin{array}{l}\text { The authors analyzed whether the sustainability reporting quality would affect } \\
\text { corporate financial performance among the firms listed on Corporate Sustainability } \\
\text { Index and examine the information disclosed in their sustainability reports. There is } \\
\text { no association between accounting and market-based variables and the reporting } \\
\text { quality, and although the quality disclosure is improving throughout the years } \\
\text { studied, the scores are still low. }\end{array}$ \\
\hline $\begin{array}{l}\text { Latan et al. } \\
\text { (2018) }\end{array}$ & $\begin{array}{l}\text { The authors examined the effect of the combination of corporate environmental } \\
\text { strategy, top management commitment, and environmental uncertainty, with a focus } \\
\text { on the role of environmental management accounting (EMA), on corporate } \\
\text { environmental performance. There is a positive and significant influence between } \\
\text { those organizational resources (corporate environmental strategy, top management } \\
\text { commitment, and environmental unctainty) on the use of EMA, which in turn can } \\
\text { improve the environmental performance of companies. }\end{array}$ \\
\hline $\begin{array}{l}\text { Rodrigues } \\
\text { (2018) }\end{array}$ & $\begin{array}{l}\text { The author shown the informational dynamics that take place between a firm and its } \\
\text { stakeholders with respect to corporate environmental management. The results } \\
\text { suggest that the informational dynamics are composed of multiple related patterns } \\
\text { that are associated with different levels of interactions from stakeholders, who are } \\
\text { most involved when they combine disclosure patterns around key environmental } \\
\text { issues for the forest industry. }\end{array}$ \\
\hline
\end{tabular}

The concern that society has shown with environmental issues has led organizations to report information related to the subject. Even if the disclosure of this information is not mandatory, there is a clear strategic bias and competitive advantage.

\section{METHODOLOGY}

This research addresses a case study on the recognition and disclosure of environmental provisions and contingencies from Brumadinho and Mariana environmental disasters by Vale and Samarco, two mining industries. The method employed in this case study was a content analysis that uses systematic and objective procedures to describe the content of the texts (BARDIN, 2011).

The data were collected from the annual financial statements of Samarco and Vale over 10 years (from 2010 to 2019). Searching for the key words: provisions, contingencies, processes and dams. The study fits into a qualitative and exploratory framework, which, according to Creswell (2014), is through which it is possible to examine and reflect on some perceptions of society.

In this paper, data collection was carried out from Vale Financial Statements, Reference Form and the company's 'press' channel (website), and also from Samarco Financial Statements, Reference Form and the company's 'press' channel (website) (Table 2). 
Table 2 - data collected

\begin{tabular}{|c|c|c|c|c|}
\hline Companies & \multicolumn{2}{|c|}{ Vale } & \multicolumn{2}{|c|}{ Samarco } \\
\hline Years & Contingency Fund & Financial Statements & Contingency Fund & Financial Statements \\
\hline 2010 & $\mathrm{x}$ & $\mathrm{X}$ & $\mathrm{x}$ & $\mathrm{x}$ \\
\hline 2011 & $\mathrm{x}$ & $\mathrm{X}$ & $\mathrm{x}$ & $\mathrm{x}$ \\
\hline 2012 & $\mathrm{x}$ & $\mathrm{x}$ & $\mathrm{x}$ & $\mathrm{x}$ \\
\hline 2013 & $\mathrm{x}$ & $\mathrm{X}$ & $\mathrm{x}$ & $\mathrm{x}$ \\
\hline 2014 & $\mathrm{x}$ & $\mathrm{X}$ & $\mathrm{x}$ & $\mathrm{x}$ \\
\hline 2015 & $\mathrm{x}$ & $\mathrm{x}$ & $\mathrm{x}$ & $\mathrm{x}$ \\
\hline 2016 & $\mathrm{x}$ & $\mathrm{X}$ & $\mathrm{x}$ & $\mathrm{x}$ \\
\hline 2017 & $\mathrm{x}$ & $\mathrm{x}$ & $\mathrm{x}$ & $\mathrm{x}$ \\
\hline 2018 & $\mathrm{x}$ & $\mathrm{x}$ & $\mathrm{x}$ & $\mathrm{x}$ \\
\hline 2019 & $\mathrm{x}$ & $\mathrm{x}$ & $\mathrm{x}$ & - \\
\hline
\end{tabular}

At a company-level, we focus to investigate the provision of liabilities related to lawsuits and lawsuits deposits related to environmental damage caused by the Mariana and Brumadinho dam disasters. In addition, we analyze how environmental contingencies were recognized and disclosed between 2010 and 2019. As well as checking Mariana's post-tragedy investments to prevent other environmental disasters. It is worth mentioning that Samarco had not yet published the 2019 Financial Statements on the date information was collected.

\subsection{COMPANIES DESCRIPTION}

\subsubsection{Vale S.A.}

Vale, which until 2007 was called Vale do Rio Doce Company, is a Brazilian multinational mining company and one of the largest logistics operators in the country. Today, it is one of the largest mining companies in the world and the largest producer of iron ore, pellet, nickel, manganese, ferroalloy, copper, bauxite, potassium, kaolin, alumina and aluminum. In the electricity sector, the company participates in consortia and currently operates nine hydroelectric plants in Brazil, Canada and Indonesia.

Created for the exploration of the iron mines in the Itabira region in the state of Minas Gerais in 1942 under the Getúlio Vargas government, Vale is today a privately held, publicly traded company based in Rio de Janeiro, with shares traded in the Sao Paulo Stock Exchange (BM; FBOVESPA), the Paris Stock Exchange (L15) (NYSE Euronext (L16), the Madrid Stock Exchange (L17) (LATIBEX (L18) and the New York Stock Exchange (NYSE)), as part of the Dow Jones Sector Titans Composite Index. Vale was listed on the Hong Kong Stock Exchange (L19) (R4) (HKEx) (L20) (R5) from 2010 until July 2016. 
It operates in 14 brazilian states and on five continents, has about 2,000 km of rail network and nine own port terminals. It is the largest company in the iron ore and pellet market (position reached in 1974 and still holds) and the largest producer of manganese and ferroalloys in Brazil, as well as operating logistics services, which is the largest in the country. In Brazil, ores are mined by four fully integrated systems, which are composed of mine, railroad, pelletizing plant and maritime terminal (North, South and Southeast Systems). Vale consumes about $5 \%$ of all energy produced in Brazil.

On October 24, 2006, Vale announced the merger of Canadian Inco, the world's largest nickel miner, which took place during 2007. Following this merger, the new CVRD Inco business conglomerate - which changed its name in November 2007 - became the 31st largest company in the world, with a market value of 298 billion reais, ahead of IBM. In 2008 its market value was estimated at US\$ 196 billion by the consultancy Economatica ${ }^{\circledR}$, second only to Petrobras (287 billion) in Brazil, being among the ten largest companies in Latin America. On November 29, 2007, the company's trademark and trade name were just Vale S.A, a name by which it was always known on the stock exchanges, but the original corporate name was retained. In 2008, Vale do Rio Doce Company ceased to use the acronym CVRD, renamed Vale and became the 33rd largest company in the world (according to the Financial Times 2008) and the largest in Brazil in terms of volume. more than Petrobras. At the extraordinary general meeting of shareholders, held on May 22, 2009, it was decided to change the legal name of the company to Vale S.A.

In January 2012 it was voted the world's worst human rights and environmental company by the Public Eye People's, an award given since 2000 by NGOs Greenpeace and the Bern Declaration. As a result, the company was negatively marked in Brazil and worldwide by the environmental disasters of Mariana in 2015 and Brumadinho in 2019, both in the state of Minas Gerais. In both cases, there were breaches of dams belonging to the mining company, leaving hundreds of victims and missing in the mining tailings.

\subsubsection{Samarco}

Founded in 1977, Samarco is a privately held company that operates in the mining segment. Its main product is iron ore pellets sold to the steel industry in countries of the Americas, the Middle East, Asia and Europe.

With 42 years of history in the Brazilian mineral sector, the company has two operating units: Germano, in Mariana and Ouro Preto (MG), where the extraction and processing of iron 
ore was performed in three concentrators, and Ubu, in Anchieta (ES), where are four pelletizing plants. The units are interconnected by three 400-kilometer pipelines, which cross 25 municipalities in both states.

In 2015, the year in which Samarco halted its operations, 24.9 million tons were produced, $97 \%$ of which in pellets and $3 \%$ in iron ore fines. That year, the company was the 12th largest exporter in Brazil, earned US\$ 6.5 billion and generated about 6,000 direct and indirect jobs. Throughout its history, the company has always valued honoring its commitments to society and the environment and this conduct continues today. This is why the company states its dismay at the Fundão dam rupture in November 2015.

\section{ANALYSIS AND DISCUSSION OF RESULTS}

Regarding the disclosure of Vale's environmental provisions, the findings show that since 2010, there was a decrease in provisions for environmental lawsuits until 2014. Also, since 2014, there was only one lawsuit in progress from 1996, where the Itabira municipality claims compensation for environmental degradation in mining areas, as well as the immediate restoration of the affected ecological complex, in addition to the implementation of compensatory environmental programs in the region. Furthermore, Figure 1 also shows an increase for judicial deposits up to 2014, specifically, payments related to the Itabira lawsuit.

\section{Figure 1 - Environmental lawsuits and judicial deposits}

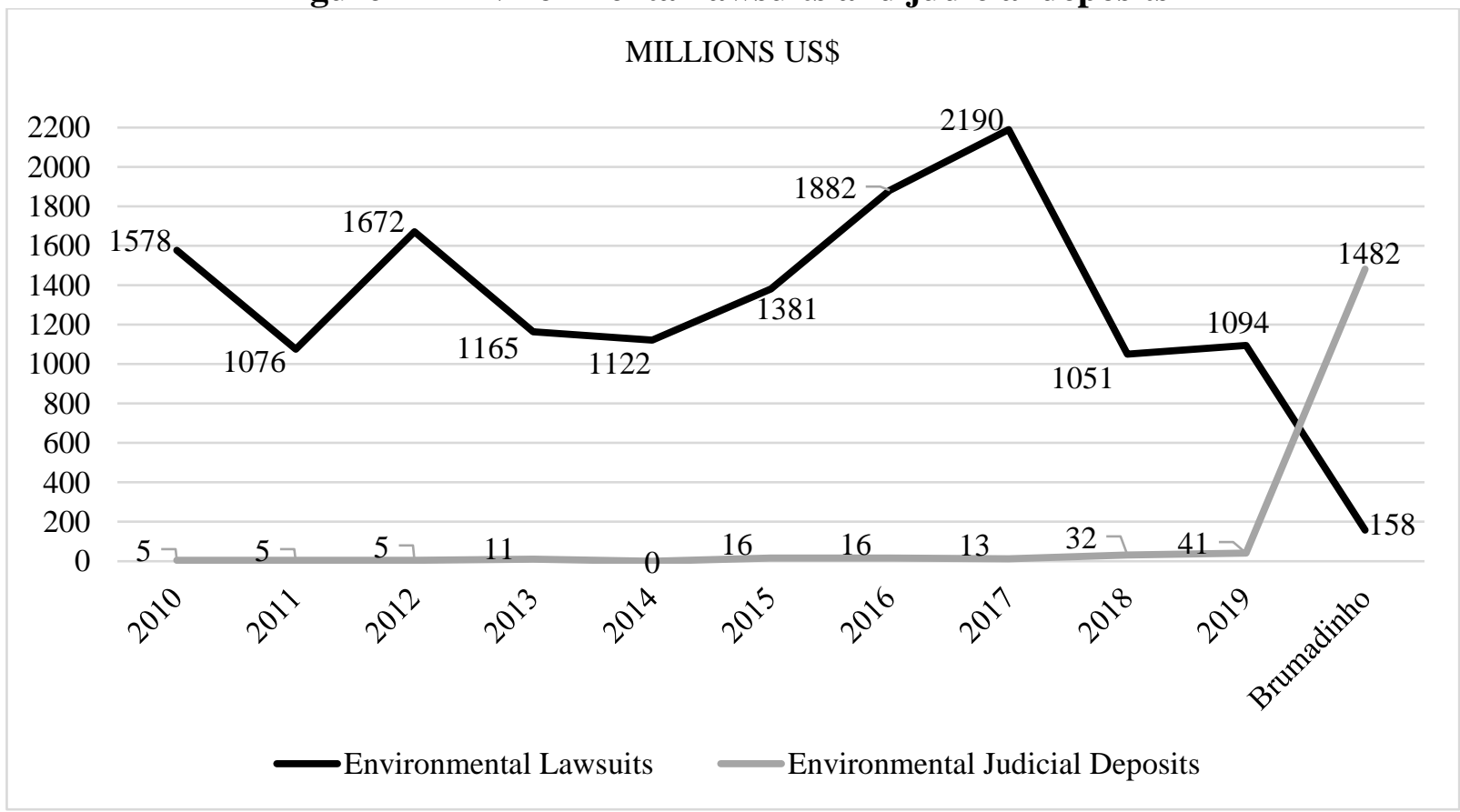


In 2015, the Mariana dam collapsed. The Mariana dam is operated by Samarco which is controlled by Vale S.A. Perhaps this explain the significant increase in the coming years regarding deposits and provisions for environmental actions filed against Samarco and Vale. The environmental lawsuits over the Brumadinho event amounted to US\$ 158 million, in addition to the 1094 already provided for the year 2019 .

The disaster caused by Samarco (2015) was already feared by the residents before the rupture (ZHOURI et al., 2016). The authors stress that the residents of Bento Rodrigues reported concern about the dams breaking, complaints about water pollution and expropriations by the company, combined with the reduction of environmental provisions by the company. This reduction reached the victims with full rights to compensation for material and moral damages.

Figure 1 shows 45 times increase between 2018 and Brumadinho. In contrast, regarding to environmental lawsuits provisions, the company did not have such a significant increase due to the slow pace of the Brazilian judicial system, which will possibly place these provisions when these lawsuits are already advanced (Figure 2).

Figure 2 - Environmental provisions (Vale and Samarco)

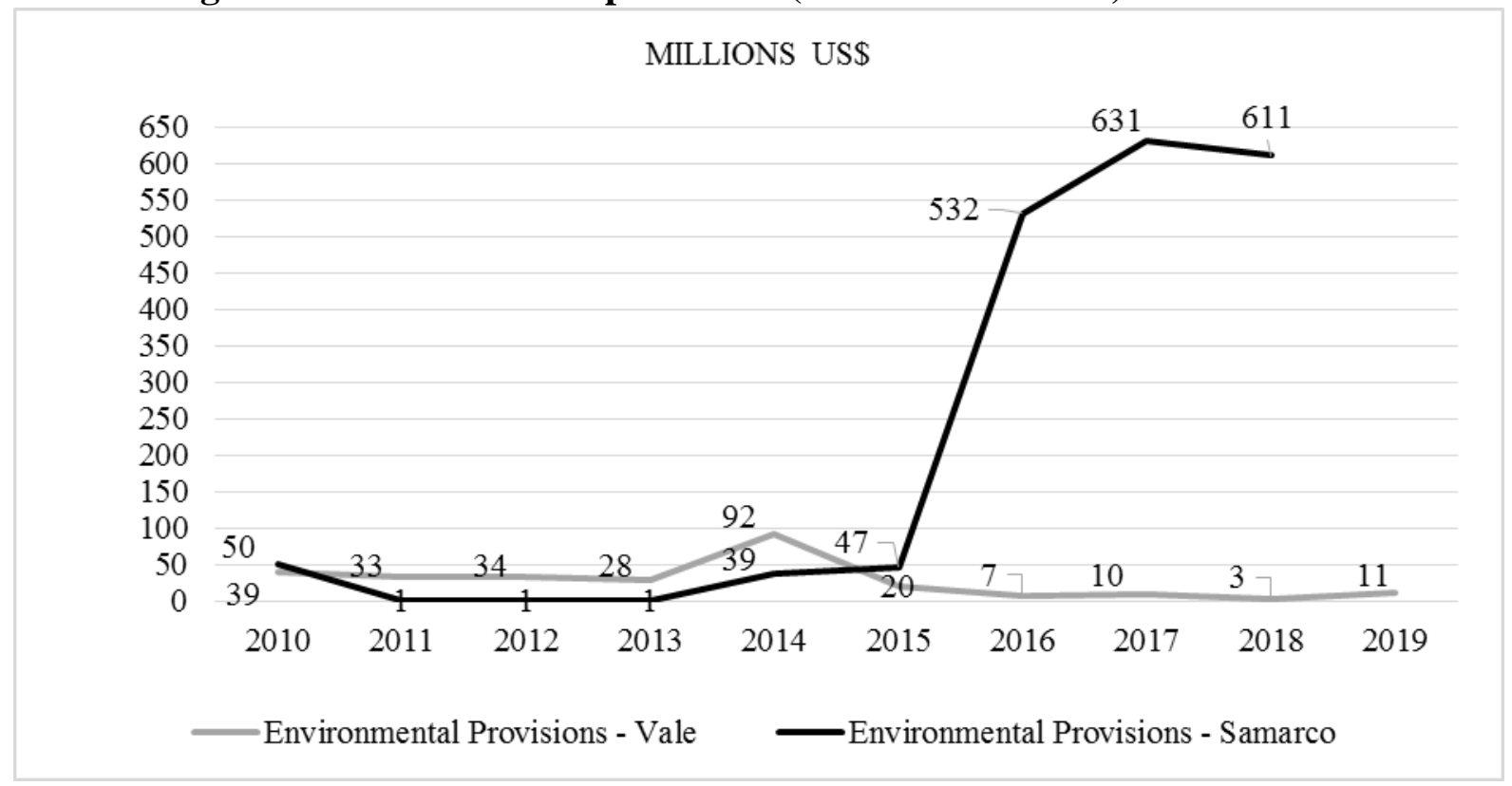

Figure 2 shows the provisions recognized by Vale and Samarco. In relation to the losses provisioned for other environmental actions, a comparison is presented between Samarco and Vale, where it can be seen that the expenses incurred increase substantially after the disaster (2015). Figure 2 does not show a significant increase in the year of the event. However, Vale has separated the provisions related to Brumadinho and, according to note 3 , the provisions are 
US\$ 6,550 million, in addition to the provisions already made in 2019. In addition, we highlight that Vale was in a year of 'recovery' of its costs related to Mariana. Samarco's information for 2019 had not yet been published.

Regarding the total provisioned liabilities, Samarco had already been showing large numbers having a peak in the provisions for the year following the disaster. Vale 2019 results did not have great peaks or provisions much higher than expected. It is noteworthy that only environmental obligations related to the Brumadinho disaster, Vale already incurred 246 million environmental obligations, and in 2019 statements, US\$ 1.568 billion in current liabilities and US\$ 1.415 million in noncurrent liabilities. In the income statement, the Brumadinho Event, as Vale calls it, has already accumulated US\$ 7.402 billion in expenses with the disaster (Figure 3).

Figure 3 - Total provisioned liabilities (Vale and Samarco)

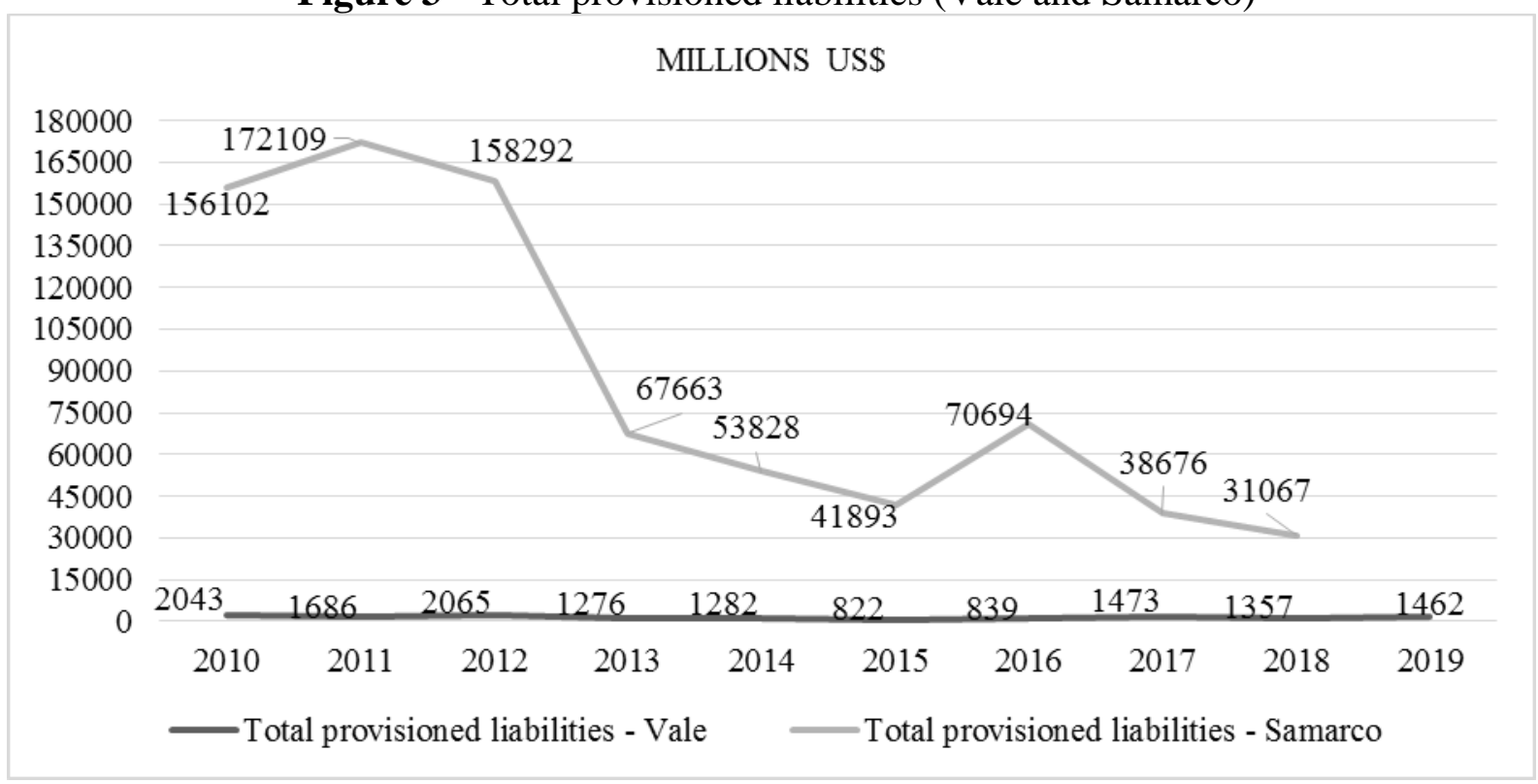

As the disaster in Mariana occurred earlier, there is more information about how much companies are provisioning and how much has already been incurred. Samarco provided more information than Vale about this accident, as it was in a mine of its own, and Vale owns 50\% of Samarco. Samarco's provisions and how much was incurred on emergency actions, remedial programs, compensatory programs and other actions not covered by the agreement are described in Table 3. 
Table 3 - Samarco Provisions

\begin{tabular}{|c|c|c|c|c|c|c|}
\hline \multirow{2}{*}{$\begin{array}{c}\text { Samarco } \\
\text { Provisions } \\
\text { (Millions of US\$) }\end{array}$} & \multicolumn{2}{|c|}{2015} & \multicolumn{2}{|c|}{2016} & \multicolumn{2}{|c|}{2017} \\
\hline & Provisioned & Incurred $^{1}$ & Provisioned & Incurred $^{1}$ & Provisioned & Incurred $^{1}$ \\
\hline $\begin{array}{l}\text { Emergency and } \\
\text { migratory actions }\end{array}$ & 304.831 & 90.184 & - & - & - & - \\
\hline $\begin{array}{l}\text { Remedial } \\
\text { programs }\end{array}$ & 5.920 .148 & 34.483 & 3.952 .511 & 1.618 .49 & 7.616.117 & 415.836 \\
\hline $\begin{array}{l}\text { Compensatory } \\
\text { programs }\end{array}$ & 3.296 .438 & - & 2.760 .202 & 11.915 & 2.910 .668 & 8.084 \\
\hline $\begin{array}{l}\text { Other actions not } \\
\text { contemplated in } \\
\text { the agreement }\end{array}$ & 483.385 & 19.683 & 498.399 & 438.257 & 727.138 & 142.609 \\
\hline Total & 10.004 .802 & 144.350 & 7.211 .112 & 2.068 .663 & 11.253 .923 & 566.529 \\
\hline
\end{tabular}

In addition to the provisions for compensation and agreements, the Company has conducted negotiations and signed into agreements with the competent authorities, as well as with the people affected by the event. Also, Vale signed into donation terms for the municipality of Brumadinho, institutions, families with missing or deceased loved ones, families living and developing productive activities in the Brumadinho Dam Self-Rescue Zone area, which totaled US\$ 2.983 million, as shown in Table 4.

Table 4 - Vale Provisions

\begin{tabular}{l|l}
\hline Vale provisions in $\mathbf{2 0 1 9}$ & In Millions of US\$ \\
\hline 1. Dam decomissioning or de-characterization (Vale) & US\$2.489 \\
\hline 1.1 Dam decomissioning or de-characterization (Joint Ventures) & US\$257 \\
\hline 2. Compensatory programs & US\$2.983 \\
\hline 2.1 Remedial Programs & US\$1.066 \\
\hline 2.2 Provision to Public Prosecution Service (labor court) claims & US\$104 \\
\hline
\end{tabular}

Furthermore, Vale announced the development of studies and projects for the restoration of vegetation and to ensure the geotechnical safety of the remaining structures at the Córrego do Feijão mine, in the amount of US\$ 1,066 million, according to Table 4. Likewise, it provided for expenses with Labor Prosecutor's Office, as on July 15, 2019, they signed a final agreement was signed to indemnify the direct and outsourced employees of the Córrego do Feijão mine that were affected by the termination of the operation. Vale states that is aware of future provisions with the Federal and State Government, the Public Defender's Office and the Public Prosecution Service, but the agreements have not yet been settled.

Vale incurred in expenses that does not qualify for the recognition of the provision and, therefore, the amounts of US\$ 730 millions were recognized directly in profit or loss for the period ended December 31, 2019, respectively. These expenses refer to communication services, accommodation and humanitarian assistance, equipment, legal services, water, food 
aid, taxes, among others. Additionally, it recorded a loss related to the downtime and idle capacity of the ferrous minerals segment recognized in the income statement as "Pre-op and downtime" in the amount of US\$ 759 millions for the period ending 31 December, 2019.

Regarding contingencies, only in the third quarter of 2019, the company released sounder information. Financial notes mention that it is subject to significant contingencies, as it is party to several judicial and administrative proceedings and that based on the evolution of these lawsuits provision can be recognized. As a result of these lawsuits, approximately US $\$ 1.6$ billion of Vale's assets are blocked as of December 31, 2019, of which approximately US\$125 million were blocked in the company's bank accounts and US $\$ 1.4$ billion were converted into assets - judicial deposits. Vale mentions at the end of the financial note about the Brumadinho event information on the measurement of provisions, which states that these provisions may be affected by: (i) changes in laws and regulations, (ii) changes in estimated current prices. direct and indirect costs related to inputs and services, (iii) changes in expected payment flow of estimated costs, (iv) changes in technologies considered in the current measurement, (v) number of persons entitled to indemnity payments, (vi) resolving potential and existing legal issues, (vii) demographic assumptions, (viii) actuarial assumptions and (ix) discount rate updates.

Finally, the amounts actually incurred by Vale may differ from the amounts currently provisioned, due to the confirmation of the recognition criteria and measurement bases, which depend on several factors, several not under the Company's control. These changes may result in a material impact on future provisions. At each reporting date, Vale will review the principal recognition criteria and measurement base used in preparing projected cash flows and adjust the provision as necessary.

Although Vale informs that it has plans to provide the necessary assistance to the victims, according to Zhouri et al. (2017), in the context of the disaster, it is necessary to observe the structures and terminologies employed by state and corporate institutions become instruments of intervention and management from outside, capable of modulating in an unprecedented way the forms of imagination and construction of identities and feelings of belonging. Vale also informs that after the Brumadinho accident, the monitoring of the company's activities was intensified and approximately 46 Board meetings were held in 2019, almost triple those we held in 2018. The Board encourages the search for excellence in operations and Vale's business as a way of ensuring the company's safety and sustainability. They promoted the acceleration of investments in alternative processes to the use of tailings dams, such as dry processing, which is expected to reach $70 \%$ of the volume of iron ore production in 2023. 
As for subsequent events, the company is attentive to COVID-19 and reported that the company may face operational difficulties related to the workforce and may need to adopt contingency measures or eventually suspend operations and that the disease outbreak did not affect the results of 2019.

Some measures have already had to be taken by the end of March. On March 16, 2020, they announced that, in order to prevent the advancement of COVID-19 to help protect the health and well-being of employees and the Nunatsiavut and Innu communities in Labrador, a decision was made to reduce operations Voisey's Bay and put it in 'care and maintenance'. On March 23, 2020, the company temporarily interrupt its distribution center in Malaysia (Maritime Terminal Teluk Rubiah), because it is temporarily unable to guarantee the minimum resources to safely operate the terminal. On March 24, 2020, the company withdrew its revolving credit lines in the amount of US\$ 5 billion as a precautionary measure, with the objective of increasing its cash position and preserving financial flexibility due to the current uncertainty in the global markets due to the COVID-19 outbreak.

\section{CONCLUSIONS}

Disasters such as those faced by Vale in Mariana and Brumadinho represent a significant change in terms of qualitative and quantitative disclosure. On the one hand, it constitutes an update of past risk scenarios, which include both safety-related intensive operation of mining activities and dams, all subsequent failed licensing, monitoring and enforcement procedures, as well as those related to environmental risks that already existed (FREITAS et al., 2019).

On the other hand, the post-tragedy effects will have consequences not only on the company's financial and reputation, but mainly on the lives of victims, families and disastrous environmental impacts. Financial stakeholders, who in some ways have greater leverage in a company may not have been privileged to listen to Vale, or perhaps they are too unaware or aware of what risk management means. Another possibility is the effect of the lack of a more equitable distribution of risks, which is an important assumption of corporate sustainability.

Although more than 1800 days have passed since the tragedy caused by Samarco, those responsible for the tragedy have not been judged. In 2019, homicide charge was withdrawn from the case. Deaths caused by the dam's rupture were considered by Justice as a consequence of the flooding caused by the rupture. During this period, destroyed communities were not rebuilt and responses for environmental recovery are still lacking (FREITAS, 2020). 
Vale created the Renova Foundation to formulate and implement restoration and compensation programs in public institutions responsible for monitoring and supervising the instituted policies (SILVA; CAYRES; SOUZA, 2019). However, the authors point out that it is a private Foundation, controlled by the defendant companies and not by the public power. In addition, it is a foundation whose management staff, in large part, originates from companies, with great expertise to deal with the market, but without experience with the production and execution of policies and issues of public interest.

Safety actions to prevent such disasters should be performed in a multidisciplinary manner (ie. engineering techniques, human health, technology management and environmental constraints), particularly in the management of environmental risks. The main tool to avoid these negative scenarios is environmental licensing. However, the environmental licensing process, approved by the new government, paves the way for new disasters. This scenario can be avoided with the requirements of the implemented and inspected environmental law (CIONEK et al., 2019).

Conner (2015) highlights that while there are both international and national regulations regarding best practices, many of the risks these corporations face are site specific, requiring detailed background research and precautionary measures that cannot be solved using a generalized framework. To address these concerns, companies must develop their risk management systems and operational practices to minimize harmful environmental impacts and incidents and by embedding environmental concerns into all aspects of daily operations, these companies can achieve socially beneficial outcomes, while avoiding potential disasters and more stringent legislation.

In these cases, when analyzing the facts, most of the environmental licenses were up to date, but since 2012 Vale has been fighting against the title of worst company in the world, regarding human rights and environment, by the 'Public Eye People's', by the NGOs Greenpeace and the Bern Declaration, which was indicative since that time about the risks that this company brought to the environment.

Despite stakeholders, agencies, governors and securities commissions requiring listed companies to comply with accounting standards and disclosure provisions, it is often alleged that companies' annual and quarterly reports do not contain enough information other than the disclosure requirements stipulated by the regulators. This information shows not only in poor voluntary and mandatory disclosure, but meanly also poor laws and companies' disclosure compliance on the part of the companies systems. 
Mariana and Brumadinho represented a warning that the path to industrialization, for developing countries in general and Brazil in particular. Without government pressure, effectively enforced laws, good accounting and reporting, environmental monitoring, effectively likelihood of environmental risks, contingencies and provisions are critical.

Finally, Vale's environmental and accident prevention investments were analyzed and, already mentioned, and only the installation of a second reheating furnace with state-of-the-art technology was the only finding. And in 2012, after being awarded as the worst company, they invested in environmental protection and conservation, and in social and economic mobility projects.

It is therefore suggested that further studies that include other ore companies and ore production of different dimensions should be included in the sample to establish further evidence on the sector. Different sectors that are also polluting and that can leave the surrounding communities vulnerable can also be investigated.

Fahlevi, Indriani and Mulyany (2019) concludes in theis study that accounting has a role beyond a mere passive recording of events. In the context of disasters, accounting can provide not only a calculative mechanism for reporting, but also facilitates communication among the stakeholders, monitors and evaluates disaster recovery projects (FAHLEVI; INDRIANI; MULYANY, 2019).

In this way, it is possible to gain a greater understanding of the sector's contribution to the economic development of society and the company's location, including its support to local communities and to better investigate preventive measures to avoid disasters of this magnitude.

Another opportunity for future research is to assess how the company will perform during COVID-19 crisis, after experiencing a considerable downturn in 2019, and investing in several countries affected by the pandemic. One of the limitations of the research was the nonpublication of Samarco's financial statements at the date of data collection.

\section{REFERENCES}

ALAZZANI, A,; WAN-HUSSIN, W. N. Global Reporting Initiative's environmental reporting: A study of oil and gas companies. Ecological indicators, 32, 19-24, 2013.

BARDIN, L. Análise de conteúdo. São Paulo: Edições 70, 2011.

BECKE, V. L. Contabilidade Social: do balanço social ao informe de sustentabilidade.

Revista Mineira de Contabilidade, ano V, 13, 12-22, 2004. 
CARMO, F. F., KAMINO, L. H. Y., JUNIOR, R. T., DE CAMPOS, I. C., DO CARMO, F. F., SILVINO, G., ...; PINTO, C. E. F. Fundão tailings dam failures: the environment tragedy of the largest technological disaster of Brazilian mining in global context. Perspectives in ecology and conservation, 15(3), 145-151, 2017.

CHING, H. Y., GERAB, F.; TOSTE, T. H. The quality of sustainability reports and corporate financial performance: Evidence from Brazilian listed companies. SAGE Open, 7(2), $2158244017712027,2017$.

CHO, C. H.; FREEDMAN, M.; PATTEN, D. M. Corporate disclosure of environmental capital expenditures: A test of alternative theories. Accounting, Auditing; Accountability Journal, 25(3), 2012. DOI: 10.1108/09513571211209617

CHO, C. H.; GUIDRY, R. P.; HAGEMANN, A. M.; PATTEN, D. M. Do actions speak louder than words? An empirical investigation of corporate environmental reputation. Accounting, Organizations and Society, v. 37, p.14-25, 2012. DOI: $\underline{10.1016 / j . a o s .2011 .12 .001}$

CHEN, J. C., CHO, C. H.; PATTEN, D. M. Initiating disclosure of environmental liability information: An empirical analysis of firm choice. Journal of business ethics, 125(4), 681692, 2014.

CIONEK, V. M., ALVES, G. H. Z., TÓFOLI, R. M., FILHO, J. L. R.,; DIAS, R. M. Brazil in the mud again: lessons not learned from Mariana dam collapse, Biodiversity and Conservation, Vol. 28, No. 7, 1935-1938, 2019. https://doi.org/10.1007/s10531-019-01762-3

CONNER, H. Managing Environmental Risk in the Oil and Gas Industry. CMC Senior Theses Paper 1121, 2015. http://scholarship.claremont.edu/cmc theses/1121\%20

CPC - COMITÊ DE PRONUNCIAMENTOS CONTÁBEIS. Pronunciamento Técnico CPC 25: provisões, passivos contingentes e ativos contingentes, de 26 de junho de 2009. Available at <http://www.cpc.org.br/pdf/CPC_25.pdf〉. (accessed November 9, 2020).

CRESWELL, J. W. Research Design: Qualitative and Quantitative approaches. [s.1.] Tousand Oaks, 2014.

D'AMICO, E., COLUCCIA, D., FONTANA, S.; SOLIMENE, S. Factors influencing corporate environmental disclosure. Business Strategy and the Environment, 25(3), 178$192,2016$.

D’OLIVEIRA, R. Bento Rodrigues: Cinco anos após tragédia, só 2 casas foram concluídas. BHAZ. 2020. Available at: <https://bhaz.com.br/2020/10/23/bento-rodrigues-cinco-anosapos-tragedia-so-duas-casas-concluidas/> (accessed November 5, 2020).

ESPINDOLA, H. S.; GUIMARÂES, D. J. M. História Ambiental dos Desastres: uma agenda necessária, Tempo e Argumento, Vol. 11, No. 26, 560-573, 2019.

FAHLEVI, H. INDRIANI, M.; MULYANY, R. What is the role of accounting in disaster recovery and relief? A literature review. In: IOP Conference Series: Earth and Environmental Science. IOP Publishing, 2019. p. 012059. 
FREITAS, C. M. D., SILVA, M. A. D.; MENEZES, F. C. D. O desastre na barragem de mineração da Samarco: fratura exposta dos limites do Brasil na redução de risco de desastres, Ciência e Cultura, Vol. 68, No. 3, 25-30, 2016.

FREITAS, R. Direitos dos atingidos por tragédia em Mariana não estão sendo respeitados, dizem MPs e Defensoria. G1 Globo.com. 2018. Available at:

$<$ https://g1.globo.com/mg/minas-gerais/desastre-ambiental-em-mariana/noticia/orgaosestaduais-e-federais-de-mg-e-es-denunciam-que-direitos-dos-atingidos-pela-tragedia-emmariana-nao-estao-sendo-respeitados.ghtml> (accessed March 21, 2020).

FREITAS, R. Tragédia de Mariana, 5 anos: sem julgamento ou recuperação ambiental, 5 vidas contam os impactos no período. G1 Globo.com. 2020. Available at: $<$ https://g1.globo.com/mg/minas-gerais/noticia/2020/11/05/tragedia-de-mariana-5-anos-semjulgamento-ou-recuperacao-ambiental-5-vidas-contam-os-impactos-no-periodo.ghtml> (accessed November 5, 2020).

FREITAS, C. M. D., BARCELlOS, C., ASMUS, C. I. R. F., SILVA, M. A. D.; XAVIER, D. R. Da Samarco em Mariana à Vale em Brumadinho: desastres em barragens de mineração e Saúde, Coletiva. Cadernos de Saúde Pública, Vol. 35, e00052519, 2019.

FERREIRA, D, D. M.; BORBA, J. A.; ROSA, C. A. As contingências ambientais das empresas estrangeiras que publicam suas demonstrações financeiras em IFRS no mercado norte americano, Revista Universo Contábil, Vol. 10, No. 3, 134-154, 2014.

GRAY, R.; BEBBINGTON, J. Accounting for the environmental, 2 ed. Londres: Sage, 2001.

KIESO, D. E.; WEYGANDT, J. J.; WARFIELD, T. D. Intermediate accounting IFRS. John Wiley \& Sons, 2020.

LATAN, H., JABBOUR, C. J. C., DE SOUSA JABBOUR, A. B. L., WAMBA, S. F.,; SHAHBAZ, M. Effects of environmental strategy, environmental uncertainty and top management's commitment on corporate environmental performance: The role of environmental management accounting, Journal of cleaner production, 180, 297-306, 2018.

MAYORGA, C. Desastre de Brumadinho e os impactos na saúde mental. Cienc. Culto. São Paulo, v. 72, n. 2, pág. 06-08, abril de 2020. Available at:

$<$ http://cienciaecultura.bvs.br/scielo.php?script=sci_arttext\&pid=S0009-

67252020000200003\&lng=en\&nrm=iso>. (accessed October 29, 2020)

http://dx.doi.org/10.21800/2317-66602020000200003

MARTÍNEZ-FERRERO, J., GARCIA-SANCHEZ, I. M.; CUADRADO-BALLESTEROS, B. Effect of financial reporting quality on sustainability information disclosure. Corporate Social Responsibility and Environmental Management, 22(1), 45-64, 2015.

MEIRA, R. M., PEIXOTO, A. L., COELHO, M. A., PONZO, A. P., ESTEVES, V. G., SILVA, M. C., ...; MEIRA-NETO, J. A. Brazil's mining code under attack: giant mining companies impose unprecedented risk to biodiversity. Biodiversity and Conservation, 25(2), 407-409, 2016. 
OPAS. Desastres Naturais e Saúde no Brasil (Série Desenvolvimento Sustentável e Saúde 2). 1a. ed. Brasília: Ministério da Saúde, 2014.

PAULO DOMINGUES, E.; SOUZA MAGALHÃES, A.; FREIRE CARDOSO, D.;

CAVALCANTE SIMONATO, T.; NAHAS, M. Impactos econômicos da paralisação de parte da produção mineral em Minas Gerais decorrentes do desastre de barragem em Brumadinho.

Gestão e Sociedade, v. 14, n. 38, p. 3463-3479, 16 abr. 2020.

POLIGNANO, M. V.; LEMOS, R. S. Rompimento da barragem da Vale em Brumadinho: impactos socioambientais na Bacia do Rio Paraopeba. Cienc. Cult., São Paulo, v. 72, n. 2, p. 37-43, Available at:

$<$ http://cienciaecultura.bvs.br/scielo.php?script=sci_arttext\&pid=S000967252020000200011

\&lng=en\&nrm=iso> (accessed October 30, 2020). http://dx.doi.org/10.21800/2317-

$\underline{66002020000200011 .}$

RAMAN, A.; LIU, F. An investigation of the Brumadinho Dam Break with HEC RAS simulation. arXiv preprint arXiv:1911.05219, 2019.

REAMS, M. A., HARDING, A. K., LAM, N. S., O'CONNELL, S. G., TIDWELL, L., ANDERSON, K. A.,; SUBRA, W. Response, Recovery, and Resilience to Oil Spills and Environmental Disasters: Exploration and Use of Novel Approaches to Enhance Community Resilience. Journal of Environmental Health, 80(2), 2017.

RODRIGUES, F. P. A notícia e os mecanismos da informação objetiva e das fake news, Revista Científica UMC, Vol. 4, No. 3, 2019.

SILVA, M. Z.; CAYRES, D. C.; SOUZA, L. A. M. Desastre socioambiental e Termo de Transação e Ajustamento de Conduta (TTAC) como instrumento de política pública: o caso da barragem de Fundão, MG. Civitas-Revista de Ciências Sociais, v. 19, n. 2, p. 464-488, 2019.

SILVA, J. F. P. D. Responsabilidade social e meio ambiente: a contabilidade como ferramenta essencial ao desenvolvimento sustentável. Revista Brasileira de Gestão Ambiental e Sustentabilidade, Vol. 6, No. 12, 67-80, 2019.

SILVA, M. A., et al. Sobreposição de riscos e impactos no desastre da Vale em Brumadinho. Cienc. Cult. São Paulo, v. 72, n. 2, p. 21-28, Apr. 2020. Available at:

$<$ http://cienciaecultura.bvs.br/scielo.php?script=sci_arttext\&pid=S000967252020000200008 \&lng=en\&nrm=iso>. (accessed October 28, 2020). http://dx.doi.org/10.21800/231766602020000200008 .

SOUZA, P. A. Open data could have helped us learn from another mining dam disaster, Scientific data, Vol. 6, No. 1, 54, 2019.

VERRECCHIA, R. Essays on disclosure, Journal of Accounting and Economics, Amsterdam, V. 32, N.1-3, 97-180, Dec. 2001. DOI: 10.1016/S0165-4101(01)00025-8.

ZHOURI, A. al. O desastre da Samarco e a política das afetações: classificações e ações que produzem o sofrimento social. Ciência e Cultura, v. 68, n. 3, p. 36-40, 2016. 
ZHOURI, A.; OLIVEIRA, R.; ZUCARELLI, M.; VASCONCELOS, M. The Rio Doce Mining Disaster in Brazil: between policies of reparation and the politics of affectations. Vibrant: Virtual Brazilian Anthropology, 14 (2), 2017.

ZHOURI, A. Mineração, Violência e Resistências: um campo aberto à produção de conhecimento no Brasil. La Región Andina: ¿desarrollo sostenible con desigualdad ? 69, 2018 . 